\title{
Neutralization of interleukin-9 ameliorates symptoms of allergic rhinitis by reducing Th2, Th9, and Th17 responses and increasing the Treg response in a murine model
}

\author{
Zhao Wei Gu${ }^{1}$, Yun Xiu Wang ${ }^{2}$ and Zhi Wei Cao ${ }^{1}$ \\ ${ }^{1}$ Department of Otorhinolaryngology, China Medical University affiliated Shengjing Hospital, Shenyang, Liaoning, China \\ ${ }^{2}$ Hematological Laboratory, China Medical University Affiliated Shengjing Hospital, Shenyang, Liaoning, China \\ Correspondence to: Zhi Wei Cao, email: gordon_2134@aliyun.com \\ Keywords: interleukin-9, neutralization, Th9, allergic rhinitis, murine model, Immunology and Microbiology Section, Immune re- \\ sponse, Immunity \\ Received: April 30, 2016 \\ Accepted: January 23, 2017 \\ Published: February 07, 2017
}

\section{ABSTRACT}

A novel independent Th-cell subset, characterized by high expression of interleukin (IL)-9, has been recognized as the "Th9" subset. Although Th9 cells are important in many diseases, their contribution to allergic rhinitis (AR) remains unclear. We therefore first determined whether Th9 cells were present in a mouse model of AR. We then investigated the their involvement in the distribution of CD4+ T-cell subsets and the symptoms of AR by treating mice with anti-IL-9 antibodies (Abs). Anti-IL-9 Abs were administered intranasally during rechallenge of ovalbumin (OVA)-induced AR in BALB/C mice. We measured nasal rubbing motion, sneezing and eosinophils, as well as the Th1 (Th1 cell percentage, Ifn- $Y$ mRNA/protein, T-bet mRNA), Th2 (Th2 cell percentage, Il-4 mRNA/protein, Gata3 mRNA), Th9 (Th9 cell percentages II-9 mRNA/protein, PU.1 and Irf4 mRNA), Th17 (Th17 cell percentage, Il-17 mRNA/protein, Roryt mRNA), and Treg (Treg cell percentage, Foxp3 mRNA) responses in the nasal mucosa. Treatment with anti-IL-9 Abs markedly reduced nasal rubbing, sneezing, eosinophil infiltration, and Th2, Th9, and Th17 responses, and increased the Treg response. Our findings emphasize the importance of IL-9/Th9 in the pathogenesis of AR, and suggest that anti-IL-9 Ab treatment may be an effective therapeutic strategy for AR.

\section{INTRODUCTION}

Allergic rhinitis (AR) is one of the most prevalent airway diseases worldwide. Although AR is not lifethreatening, it seriously reduces patients' quality of life and work efficiency. AR may impair academic, workrelated, emotional, and social function, so the great social and economic burden caused by AR should not be ignored [1-3].

$\mathrm{AR}$ is characterized by the involvement of $\mathrm{CD}^{+}$ T-cell subsets and their associated immune mediators, including specific cytokines and chemokines $[4,5]$. AR has long been thought to result from the upregulation of Th2 cells and a relative lack of Th1 cells [6]. Although the Th2 cell-mediated immune response explains many characteristics of AR, this simple model of inflammation is not sufficient to explain the immune mechanism behind AR. It was found that Th1 inflammation does not become dominant even when Th2 allergic inflammation is reduced
[7], indicating that the pathogenesis of allergic disease is not entirely due to a Th1/Th2 imbalance, but is likely to involve other mechanisms, as well.

In recent years, the discovery of Th17 and regulatory $\mathrm{T}$ (Treg) cells introduced complexity into the existing Th1/ Th2 balance paradigm and expanded our understanding of the pathogenesis of AR [4]. More recently, a novel, independent Th-cell subset (the 'Th9' subset), characterized by high expression of interleukin (IL)-9, was recognized [8-10]. IL-9 affects both inflammatory and normal tissue cells, increasing the numbers of lymphocytes, eosinophils and mast cells, stimulating $\operatorname{IgE}$ secretion, enhancing the responses of mast cells to allergens, promoting mucin expression, and stimulating cytokine secretion by inflammatory cells [11-14].

The various T-cell subsets regulate inflammatory responses mainly by secreting specific cytokines, such as interferon- $\gamma$ (IFN- $\gamma$ ), IL-4, IL-5, IL-9, IL-13, and IL-17. Th9 cells were reported to be involved in the development 
of allergic asthma [15], although their precise contribution to AR remains unknown. Given that IL-9 has important functions in other inflammatory diseases, and that the use of anti-IL-9 antibodies (Abs) confers protective effects under these conditions [16-18], we reasoned that IL-9 or Th9 cells may be important contributors to AR, and that IL-9 neutralizing Ab therapy may therefore be effective against AR.

Thus, we first sought to evaluate the presence of Th9 cells and the distribution of $\mathrm{CD}^{+}{ }^{+} \mathrm{T}$-cell subsets in a mouse model of AR, and then investigated the involvement of IL-9 in the distribution of $\mathrm{CD}^{+}$T-cell subsets and the effects of IL-9 on AR by administering anti-IL-9 Abs.

\section{RESULTS}

\section{Effect of IL-9 blockade on nasal symptoms in the AR mouse model}

To evaluate the effects of anti-IL-9 Ab treatment on AR symptoms in mice, we counted the numbers of sneezes and nasal rubs after the last OVA challenge (Figure 1). Mice in group B sneezed significantly more (31.8 \pm 7.79 sneezes/10 $\mathrm{min})$ than those in group A $(2.2 \pm 1.09$ sneezes $/ 10 \mathrm{~min}, p<0.05)$. Mice treated with anti-IL-9 (group D) sneezed less (10.8 \pm 2.58 sneezes $/ 10 \mathrm{~min})$ than those in group C $(33.6 \pm 9.21$ sneezes $/ 10 \mathrm{~min}, p<0.05)$.

The effects on nasal rubbing were similar: $4.0 \pm 2.0$ $\mathrm{rubs} / 10 \mathrm{~min}$ for group A, 22.8 $\pm 2.95 \mathrm{rubs} / 10 \mathrm{~min}$ for group $\mathrm{B}, 19.4 \pm 2.70 \mathrm{rubs} / 10 \mathrm{~min}$ for group $\mathrm{C}$, and $13.4 \pm 1.52$ rubs/10 min for group $\mathrm{D}$. These results indicate that antiIL-9 treatment can alleviate the symptoms of AR.

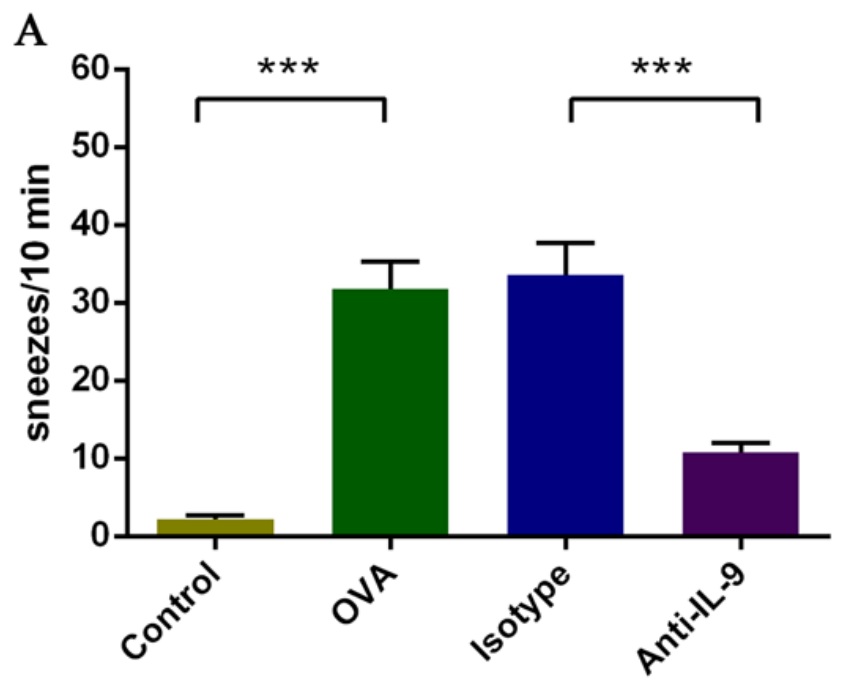

\section{Effect of IL-9 blockade on eosinophils}

Eosinophilic cytoplasm stained red with H\&E (Figure 2A). H\&E staining of the nasal mucosa revealed significantly greater infiltration of eosinophils in group B $(47.95 \pm 4.21$ cells/high-power field) than in group A $(1.55 \pm 0.21$ cells/high-power field; $p<0.05)$. In the mice treated with anti-IL-9 Abs, eosinophilic infiltration was significantly lower than in isotype-treated mice (21.55 \pm 6.46 cells/high-power field in group D versus $41.85 \pm 5.03$ cells/high-power field in group $\mathrm{C}, p<0.05$ ) (Figure 2B).

These results indicate that anti-IL-9 Ab treatment can inhibit the infiltration of eosinophils.

\section{Effect of IL-9 blockade on cytokine levels in the nasal mucosa}

To evaluate the effects of anti-IL-9 Ab treatment on Th cell-related cytokine levels in the nasal mucosa, we analyzed the protein levels of IFN- $\gamma$, IL-4, IL-9, and IL-17 by CBA (Figure 3 ).

The levels of IFN- $\gamma$, IL-4, IL-9, and IL-17 in the nasal mucosa were significantly greater in the AR group (group B) than in the control group (group $\mathrm{A} ; p<0.05$ ). The levels of these four cytokines were significantly lower in mice treated with anti-IL-9 Abs than in isotypetreated controls (group D versus group $\mathrm{C} ; p<0.05$ ). IFN- $\gamma$ levels were $36.9 \pm 3.8 \mathrm{pg} / \mathrm{mL}$ in group A, $60.0 \pm 8.3 \mathrm{pg} / \mathrm{mL}$ in group $\mathrm{B}, 60.7 \pm 13.9 \mathrm{pg} / \mathrm{mL}$ in group $\mathrm{C}$, and $37.9 \pm 3.3$ $\mathrm{pg} / \mathrm{mL}$ in group D. IL-4 levels were $16.2 \pm 2.6 \mathrm{pg} / \mathrm{mL}$ in group A, $91.3 \pm 26.3 \mathrm{pg} / \mathrm{mL}$ in group $\mathrm{B}, 95.6 \pm 24.8 \mathrm{pg} / \mathrm{mL}$ in group $\mathrm{C}$, and $38.5 \pm 2.9 \mathrm{pg} / \mathrm{mL}$ in group $\mathrm{D}$. IL-9 levels were $19.8 \pm 3.0 \mathrm{pg} / \mathrm{mL}$ in group $\mathrm{A}, 65.3 \pm 5.2 \mathrm{pg} / \mathrm{mL}$ in

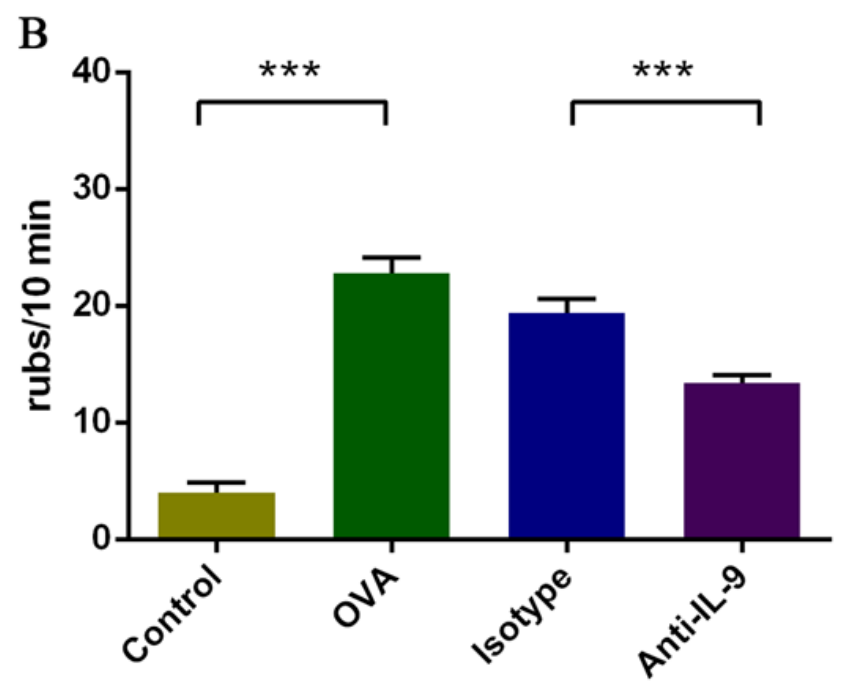

Figure 1: Inhibition of nasal symptoms resulting from IL-9 blockade. A. Sneezing symptom score. B. Rubbing symptom score. $* * * P<0.05$. 
group $\mathrm{B}, 63.4 \pm 3.8 \mathrm{pg} / \mathrm{mL}$ in group $\mathrm{C}$, and $36.3 \pm 2.0 \mathrm{pg} / \mathrm{mL}$ in group D. IL-17 levels were $3.9 \pm 0.5 \mathrm{pg} / \mathrm{mL}$ in group A, $24.8 \pm 3.4 \mathrm{pg} / \mathrm{mL}$ in group $\mathrm{B}, 24.1 \pm 3.0 \mathrm{pg} / \mathrm{mL}$ in group $\mathrm{C}$, and $14.0 \pm 0.7 \mathrm{pg} / \mathrm{mL}$ in group $\mathrm{D}$.

Based on these results, the IL-9 blockade significantly attenuated the levels of IFN- $\gamma$, IL-4, IL-9, and IL-17. These data indicate that anti-IL-9 Abs suppress inflammation of the nasal mucosa by reducing the levels of multiple inflammatory mediators therein.

\section{Effect of IL-9 blockade on mRNA expression of $\mathrm{Th}$ cell-related cytokines and T-cell subset transcription factors in the nasal mucosa}

To further evaluate the effects of anti-IL-9 Ab treatment on allergic inflammation, we performed realtime PCR to examine the mRNA expression of Th cellrelated cytokines and T-cell subset transcription factors in the nasal mucosa (Figure 4). The mRNA levels of $I l-$ $4, \mathrm{Il}-9$, and $\mathrm{Il}-17$ were greater in group $\mathrm{B}$ than in group A $(p<0.05)$. Treatment with anti-IL-9 Abs significantly reduced the mRNA levels of $\mathrm{Il}-4, \mathrm{Il}-9$, and $\mathrm{Il}-17$ (group D versus group $\mathrm{C} ; p<0.05$ ). The relative expression of $I l-4$ mRNA was $1.02 \pm 0.26$ in group A, $87.45 \pm 3.06$ in group $\mathrm{B}, 84.92 \pm 2.78$ in group $\mathrm{C}$, and $16.38 \pm 0.92$ in group $\mathrm{D}$. The relative expression of $I l-9$ mRNA was $1.03 \pm 0.26$ in group A, $20.10 \pm 1.18$ in group B, $19.50 \pm 1.73$ in group C, and $5.57 \pm 0.46$ in group D. The relative expression of $\mathrm{Il}-17$ mRNA was $1.02 \pm 0.10$ in group A, $27.41 \pm 1.77$ in group $\mathrm{B}, 23.15 \pm 1.23$ in group $\mathrm{C}$, and $15.94 \pm 1.43$ in group $\mathrm{D}$. If $n-\gamma$ mRNA levels were slightly greater in group $\mathrm{B}$ than in group A, but not significantly so $(p>0.05)$. The mRNA level of $I f n-\gamma$ was significantly lower in mice treated with anti-IL-9 Abs than in isotype-treated controls (group $\mathrm{D}$ versus group $\mathrm{C} ; p<0.05$ ). The relative expression of If $n-\gamma$ was $1.02 \pm 0.24$ in group A, $1.43 \pm 0.40$ in group $\mathrm{B}$, $1.38 \pm 0.10$ in group $\mathrm{C}$, and $1.00 \pm 0.14$ in group D.

The mRNA levels of Gata3, PU.1, Irf4 and Roryt also were significantly higher in group B than in group $\mathrm{A}(p<0.05)$ and significantly lower in group $\mathrm{D}$ than in group C $(p<0.05)$. The relative expression of Gata3 mRNA was $1.02 \pm 0.23$ in group A, $30.06 \pm 4.63$ in group $\mathrm{B}, 28.03 \pm 6.90$ in group $\mathrm{C}$, and $3.84 \pm 0.15$ in group D. The relative expression of $P U .1$ mRNA was $1.02 \pm 0.22$ in group A, $22.20 \pm 1.04$ in group B, 20.56 \pm 2.36 in group C, and $6.23 \pm 0.78$ in group D. The relative expression of Irf4 mRNA was $1.00 \pm 0.03$ in group A, $17.23 \pm 1.11$ in group $\mathrm{B}, 15.94 \pm 0.83$ in group $\mathrm{C}$, and $7.33 \pm 0.81$ in group $\mathrm{D}$. The relative expression of Roryt mRNA was $1.00 \pm 0.10$ in group A, $19.39 \pm 3.05$ in group B, $18.80 \pm 2.47$ in group C, and 11.47 \pm 1.49 in group D. T-bet mRNA levels did not differ significantly among the four groups. The relative expression of T-bet mRNA was $1.00 \pm 0.13$ in group $\mathrm{A}, 0.87 \pm 0.05$ in group $\mathrm{B}, 0.86 \pm 0.25$ in group $\mathrm{C}$, and $0.85 \pm 0.10$ in group D.

Foxp 3 mRNA expression was significantly lower in group B than in group A $(p<0.05)$. The mRNA levels of Foxp3 were significantly greater in mice treated with antiIL-9 Abs than in isotype-treated controls (group D versus group $\mathrm{C} ; p<0.05$ ). The relative expression of Foxp3 mRNA was $1.02 \pm 0.24$ in group A, $0.44 \pm 0.15$ in group B, $0.34 \pm 0.04$ in group $\mathrm{C}$, and $0.71 \pm 0.08$ in group $\mathrm{D}$.

These results suggest that anti-IL-9 Abs block allergic inflammation by inhibiting the mRNA expression of cytokines and specific transcription factors in Th2, Th9, and Th17 cells, and by increasing the expression of specific transcription factors in Tregs. The mRNA levels of Th1 cell-specific transcription factors and related cytokines do not seem to be affected.

\section{Effect of IL-9 blockade on T-cell subsets in the nasal mucosa}

To evaluate the effects of anti-IL-9 Ab treatment on the lymphocytic immune response, we examined the percentages of T-helper cell subsets and Treg cells in the nasal mucosa using flow cytometry (Figure 5). The Th2, Th9, and Th17 cell percentages were greater in group B than in group A $(p<0.05)$. The percentages of these subsets were significantly lower in mice treated with anti-
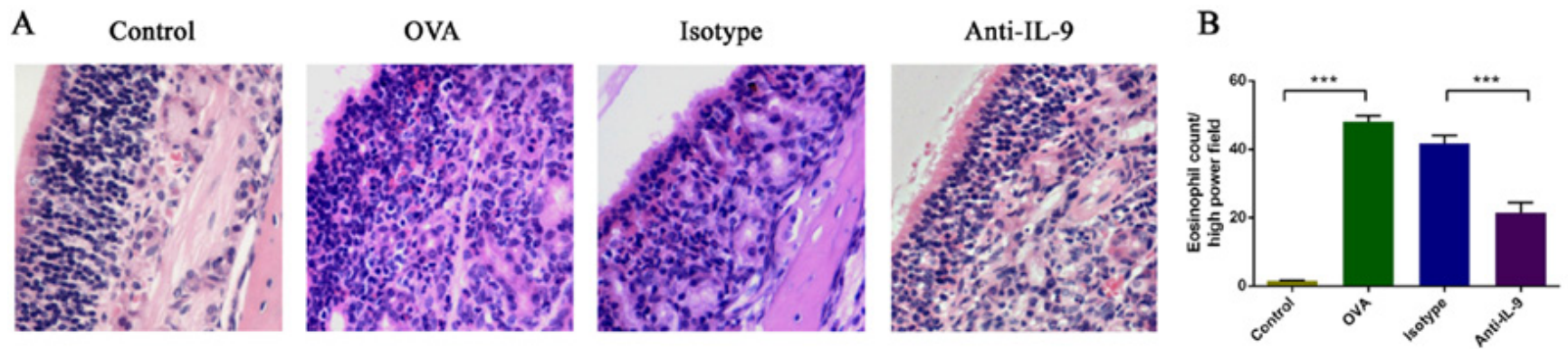

Figure 2: Anti-IL-9 Abs reduced the infiltration of eosinophils in the nasal mucosa. Representative photomicrographs (original magnification $\times 200$ ) of nasal mucosal sections from mice, stained with hematoxylin and eosin (H\&E) for eosinophils A. Significantly greater numbers of eosinophils B. were observed in the OVA group than in the control group, and this increase was obviously alleviated by anti-IL-9 Ab treatment. $* * * P<0.05$. 
A

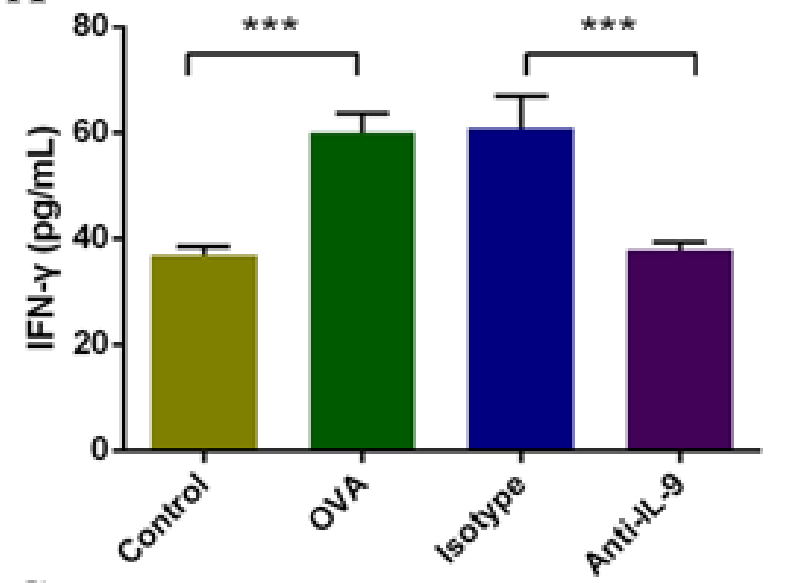

C

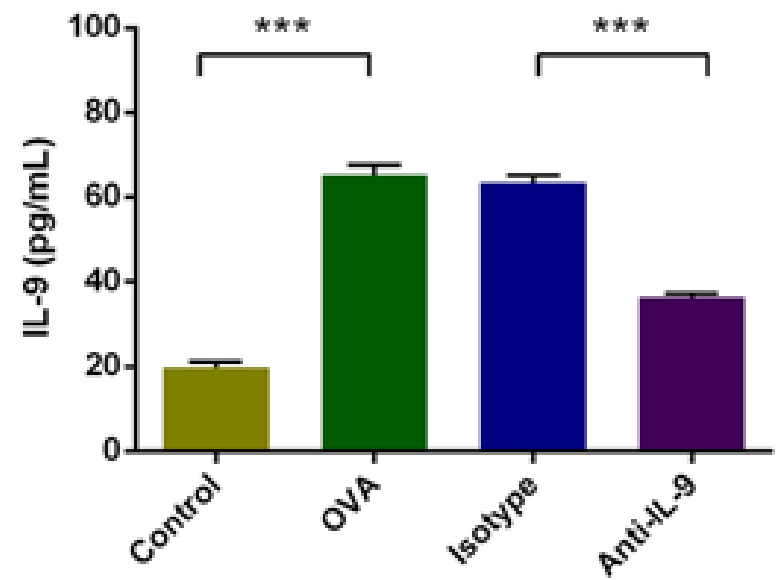

B

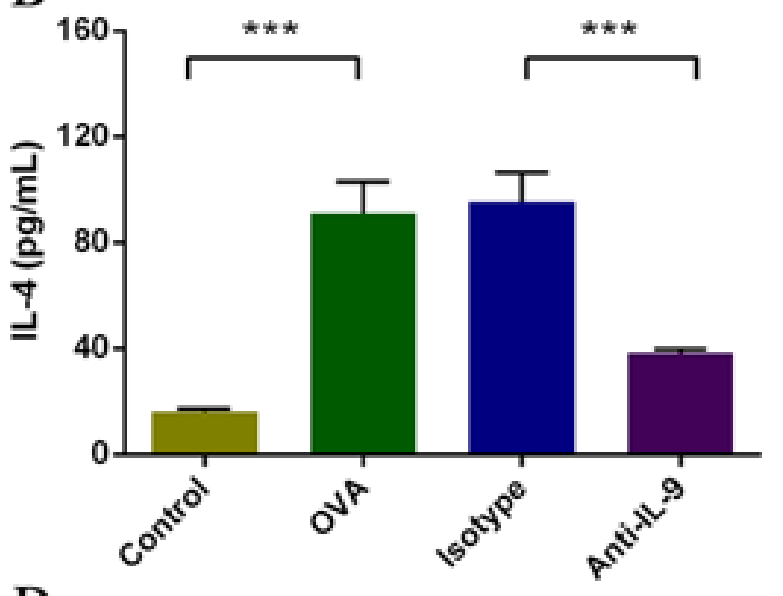

D

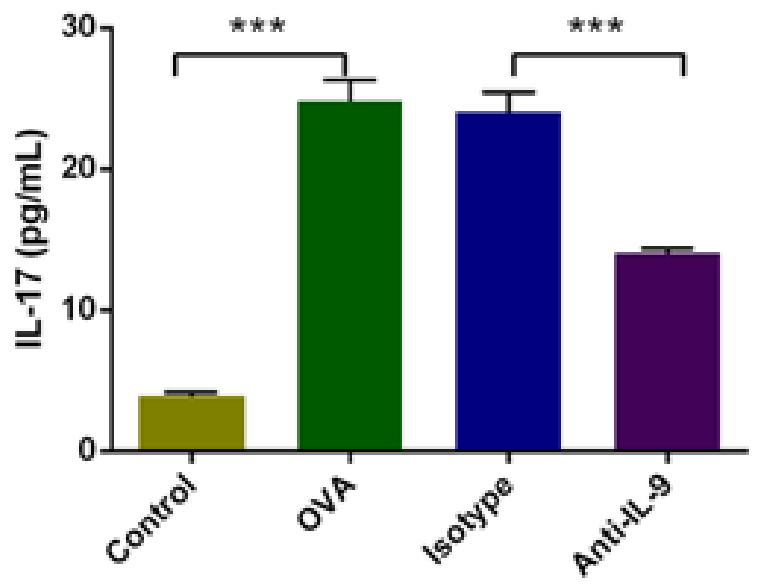

Figure 3: Anti-IL-9 reduced Th cell-related cytokine levels in the nasal mucosa. The protein levels of IFN- $\gamma$, IL-4, IL-9, and IL-17 A., B., C., and D. were analyzed by CBA. The levels of all cytokines in the nasal mucosa were significantly greater in the OVA group than in the control group, and were markedly lower in the anti-IL-9-treated group than in the isotype-treated group. ${ }^{* * *} P<0.05$.

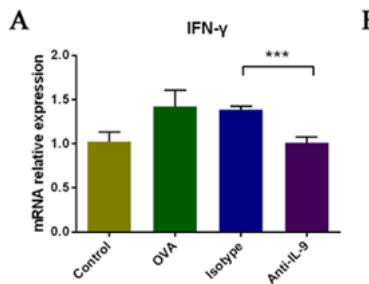

F

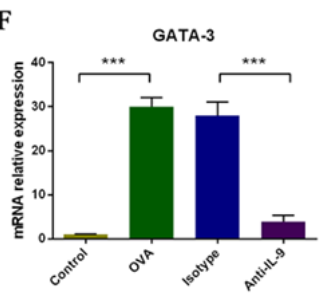

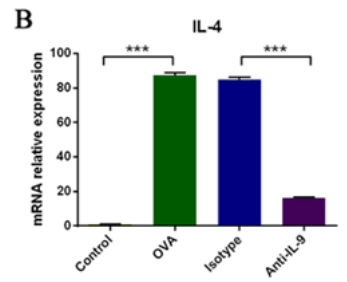

G

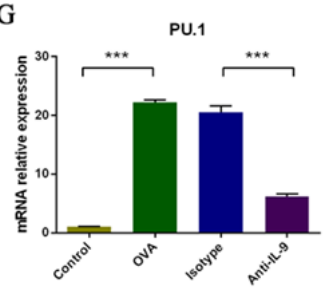

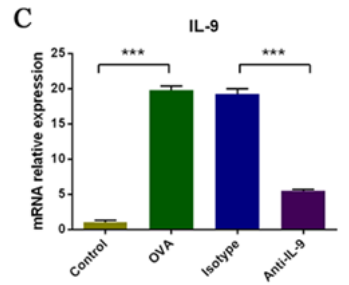

D

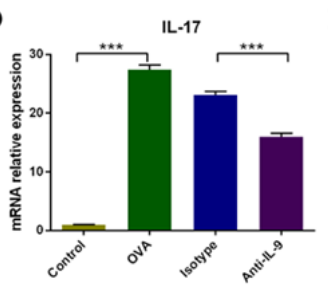

$\mathrm{H}$

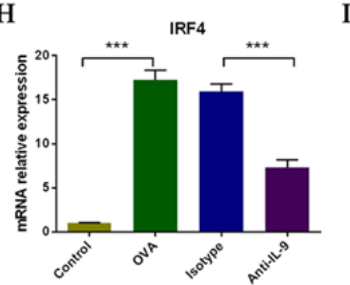

I

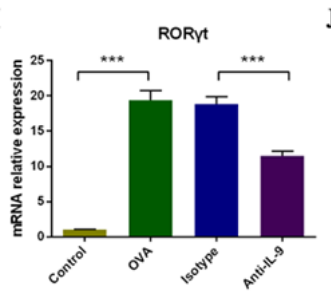

$\mathrm{E}$

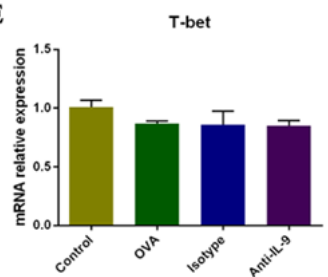

$\mathbf{J}$

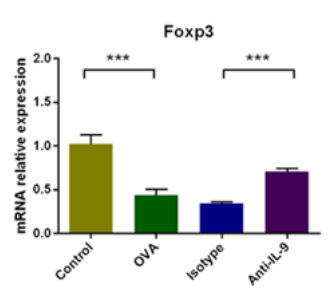

Figure 4: The effect of IL-9 blockade on the mRNA expression of Th cell-related cytokines and T-cell subset transcription factors in the nasal mucosa, analyzed with real-time PCR. The relative levels of Il-4, Il-9, Il-17, Gata3, PU.1, Irf4 and Roryt mRNA B., C., D., F., G., H., and I. were significantly greater in the OVA group than in the control group, and this upregulation was markedly inhibited by anti-IL-9 Abs. Ifn- $\gamma$ mRNA levels were moderately but not significantly greater in the OVA group than in the control group, but were significantly downregulated with anti-IL-9 Abs A. There was no significant difference in T-bet mRNA levels among the groups (E). Foxp3 mRNA levels were significantly lower in the OVA group than in the control group, and were significantly upregulated with anti-IL-9 Abs $\mathbf{J} . * * * P<0.05$. 
IL-9 Abs than in those treated with isotype Abs (group $\mathrm{D}$ versus group $\mathrm{C} ; p<0.05)$. The Th2 cell percentage was $4.58 \pm 0.15 \%$ in group A, $11.99 \pm 0.84 \%$ in group $\mathrm{B}, 12.55 \pm 1.00 \%$ in group $\mathrm{C}$, and $6.97 \pm 0.61 \%$ in group D. The Th9 cell percentage was $4.60 \pm 0.27 \%$ in group A, $11.94 \pm 1.08 \%$ in group B, $12.44 \pm 0.48 \%$ in group C, and $6.34 \pm 0.32 \%$ in group $\mathrm{D}$. The Th17 cell percentage was $4.87 \pm 0.43 \%$ in group A, $17.44 \pm 0.50 \%$ in group B, $15.60 \pm 1.37 \%$ in group $\mathrm{C}$, and $8.37 \pm 0.35 \%$ in group $\mathrm{D}$. The Th1 cell percentage did not differ significantly among the four groups. The Th1 cell percentage was $6.45 \pm 0.09 \%$ in group A, $6.27 \pm 0.10 \%$ in group $\mathrm{B}, 6.01 \pm 0.11 \%$ in group $\mathrm{C}$, and $6.13 \pm 0.09 \%$ in group D.

The Treg cell percentage was lower in group B than in group $\mathrm{A}(p<0.05)$. The Treg cell percentage was significantly greater in mice treated with anti-IL-9 Abs than in isotype-treated controls (group D versus group C; $p<0.05)$. The Treg cell percentage was $18.51 \pm 1.50 \%$ in group A, $6.31 \pm 0.55 \%$ in group B, $7.04 \pm 0.54 \%$ in group C, and $10.32 \pm 0.67 \%$ in group D.

\section{DISCUSSION}

Recently, a novel, independent Th-cell subset (the 'Th9' subset) was recognized, which is characterized by high expression of IL-9. Th9 cells are involved in various forms of inflammation [15]. PU.1 and IRF4 are key proteins that contribute to the Th9 phenotype and are essential transcription factors in Th9 cells [10, 19]. Although Th9 cells are thought to function in many diseases, their effects in AR have not been clear. We demonstrated for the first time that the Th9 cell proportion was significantly greater in AR mice than in controls. The mRNA levels of PU.1 and Irf4 (encoding Th9 cell transcription factors) and the mRNA/protein levels of Il-9 were also significantly elevated in AR. These results suggest that the Th9 response is central to the pathogenesis of AR.

AR is characterized by the accumulation of eosinophils and mast cells. Previous research has indicated
A
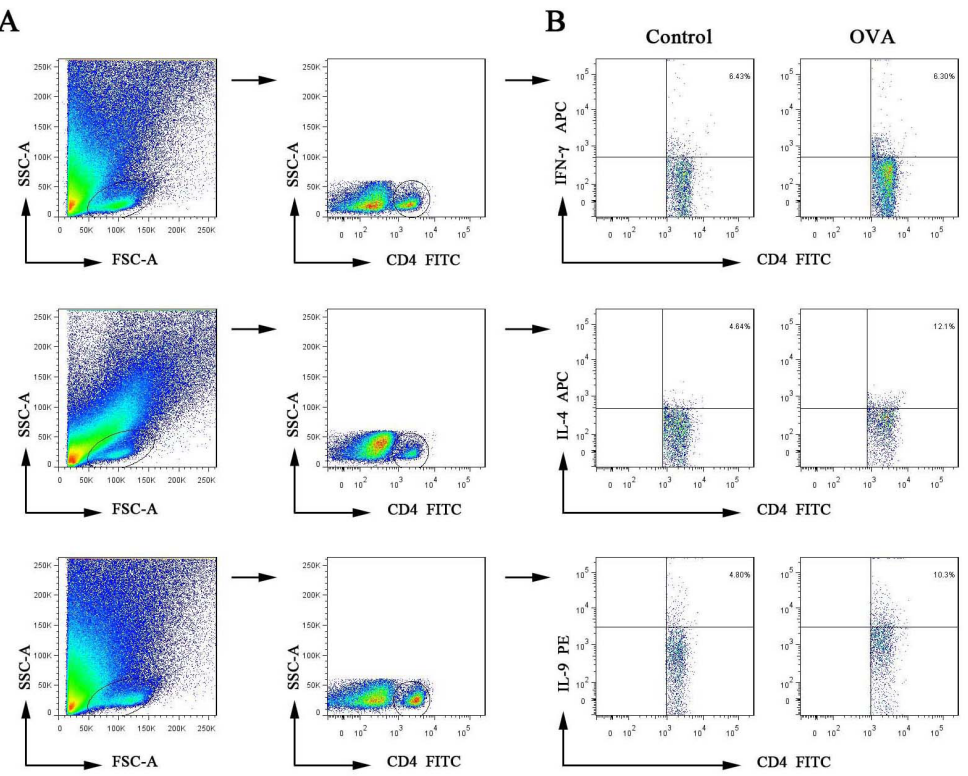

CD4 FITC
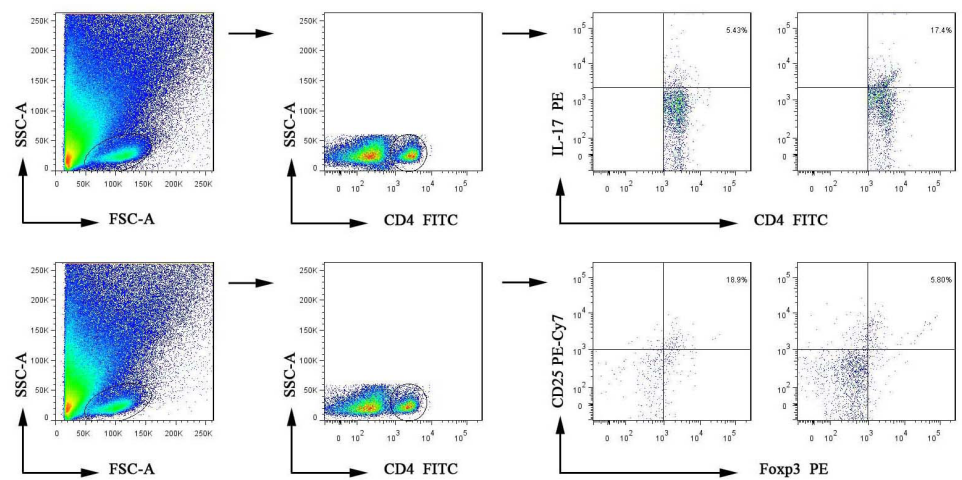

OVA
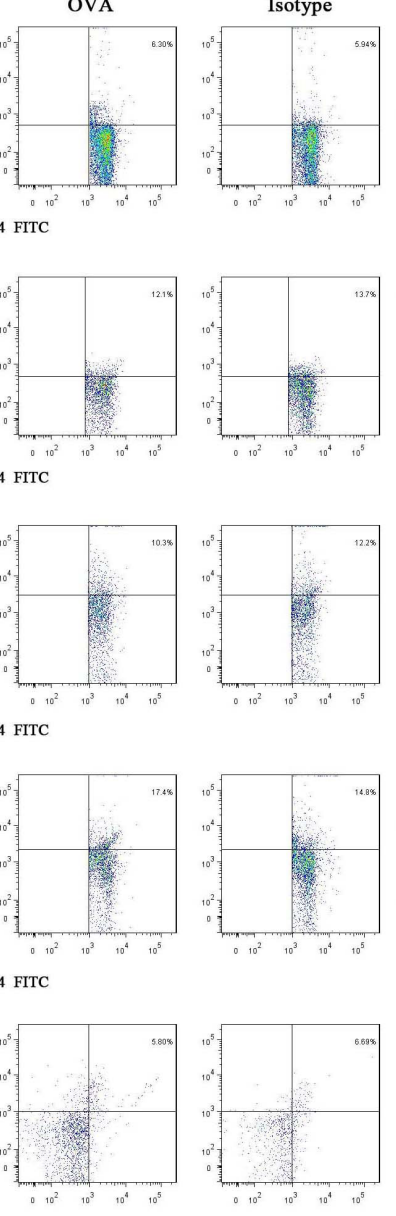
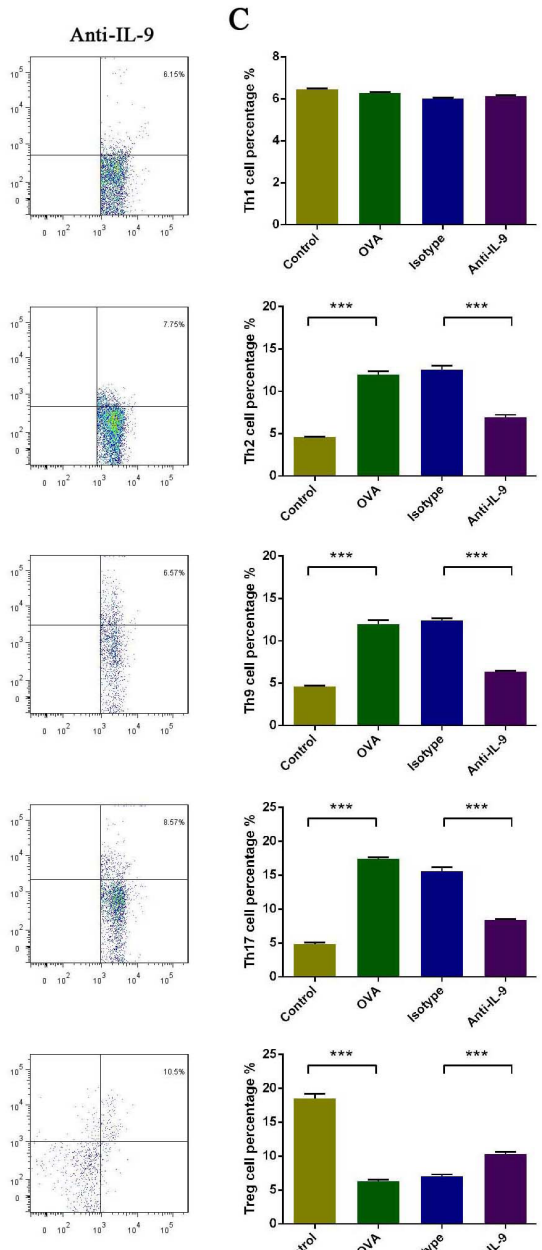

Figure 5: Effect of anti-IL-9 Ab treatment on the percentage of T-helper cell subsets and Treg cells in the nasal mucosa, analyzed by flow cytometry. Gating of $\mathrm{CD}^{+} \mathrm{T}$ cell populations A.. Data are presented as representative results of four independent experiments B. and a statistical graph $\mathbf{C}$. The numbers in the upper right quadrant are the percentages of T-helper cell subsets or Treg cells among $\mathrm{CD}^{+}$cells in gated populations of $\mathrm{CD} 4^{+} \mathrm{T}$-cells $(\mathrm{B}) . * * * P<0.05$. 
that IL-9 affects both inflammatory and normal tissue cells, increasing the numbers of lymphocytes, eosinophils, and mast cells, enhancing the responses of mast cells to allergens, and promoting mucin expression [11-14]. Considering the effects of IL-9 on eosinophils and the important functions of eosinophils in AR, we blocked IL-9 to determine its influence on eosinophils in AR. The use of IL-9 neutralizing Abs significantly inhibited eosinophil infiltration, and symptoms improved significantly. Given their significant effects on AR symptoms, anti-IL-9 Abs have the potential to treat AR.

Th cells and their secreted cytokines are central promoters of the migration, apoptosis, and function of eosinophils and mast cells in AR [4]. Th1 cells secrete IFN- $\gamma$ as part of the cellular immune response, while Th2 cells secrete IL-4, IL-5, and IL-13 as part of the humoral immune response. IL-5 can stimulate the development of eosinophils in the bone marrow and their exit into the circulation, while IL-4 and IL-13 can upregulate chemotactic factors like eotaxin to promote eosinophil infiltration.

Our knowledge of CD4 $4^{+}$T-cell differentiation has changed significantly, and new subsets, such as Th17 and Treg cells, continue to be recognized [17]. Importantly, the recent discovery of Th9 cells, the CD4 ${ }^{+} \mathrm{T}$-cell subset that produces IL-9, has expanded significantly [20]. Under certain conditions, IL-9 can have pleiotropic effects on Th1, Th2, Th17, Treg, and Th9 cells, functioning in different ways depending on the microenvironment [2127]. Considering the effects of IL-9 on Th cells and the important functions of Th cells in AR, we blocked IL-9 to determine its influence on the differentiation of Th-cell subsets in AR.

We found that the Th1 cell percentage and T-bet mRNA level did not differ significantly between AR mice and controls, and were unchanged by anti-IL-9 treatment during the OVA challenge. However, If $n-\gamma$ protein and mRNA levels were greater in AR mice than in controls, and were downregulated by anti-IL-9 treatment during the OVA challenge. The apparent inconsistency between If $n-\gamma$ and $T$-bet expression was not very surprising; it was reported that IFN- $\gamma$ is secreted by various types of cells, including Th1 cells, macrophages, and epithelial cells, but T-bet is only expressed by Th1 cells [4]. This suggests that there is some other pathway that regulates IFN- $\gamma$, and that the Th1 response is not central to the pathogenesis of AR.

We found that $\mathrm{Th} 2$ responses (the Th2 cell percentage, Il-4 mRNA/protein level, and Gata3 mRNA level) were greater in AR mice than in controls and were downregulated by anti-IL-9 treatment, suggesting that antiIL-9 Abs can suppress Th2 reactions. Indeed, inhibition of the Th2 response with anti-IL-9 Abs improved symptoms of AR.

The discovery of Th17 and Treg cells enhanced the understanding of the pathogenesis of AR. Th17 cells were first identified as IL-17-producing cells in 2000 [28], and
ROR $\gamma$ t, a transcription factor in mice, was discovered in 2006 [29]. Th17 cells have been associated with Th2predominant allergic diseases. Increased Th17 responses have been found in asthma, AR, and nasal polyps [30-33]. Consistent with previous reports $[4,30]$, we found that Th17 responses (the Th17 cell percentage, $I l-17$ mRNA/ protein level, and Roryt mRNA level) were greater in AR mice than in controls, and were downregulated with anti-IL-9 Ab treatment, suggesting that anti-IL-9 Abs can suppress Th17 reactions.

Treg cells express the specific transcription factor FOXP3 and are critical for preventing immune activation and suppressing inflammatory lesions [5]. Unlike other effector $\mathrm{CD}^{+} \mathrm{T}$ cells, Treg cells have been implicated in peripheral tolerance as inhibitors of immune responses. These cells suppress effector T cells of either the Th1 or Th2 phenotype when the latter types of cells are involved in inflammatory processes. Previous studies have found that FOXP3 mRNA expression was reduced in AR subjects [34-36]. We found that Treg responses (Treg cell percentage, Foxp 3 mRNA) were lower in AR mice than in controls and were upregulated by anti-IL-9 Ab treatment. Anti-IL-9 treatment reportedly increases "signal transducer and activator of transcription" 5 (STAT5) expression and suppresses STAT3 mRNA expression [26, 37]. STAT5 binds directly to the $F O X P 3$ gene and is required for optimal induction of FOXP3 in vitro [37,38], while STAT3 is required for IL-6-dependent downregulation of FOXP3 [38]. This suggests anti-IL-9 Abs increase the Treg cell number principally by regulating the STAT3 and STAT5 signaling pathways [37-40].

As noted, we found that Th9 responses (the Th9 cell percentage, $I l-9 \mathrm{mRNA}$ /protein level, PU.1 and Irf4 mRNA levels) were greater in AR mice than in controls, while the increased Th9 responses were significantly downregulated by anti-IL-9 treatment in AR mice.

Our results indicate that the ratios of Th2, Th9, and Th17 cells increased, while the proportion of Treg cells decreased, in the AR state. After anti-IL-9 treatment, the proportion of Th2, Th9, and Th17 cells decreased, whereas the proportion of Treg cells increased, but the proportion of Th1 cells did not change significantly. Thus, in AR, Th2, Th9, Th17, and Treg cells are important components of lymphoid immunity.

It is accepted that Th9 cells are not the only source of IL-9; upon stimulation or under special circumstances, other cells have been reported to produce small amounts of IL-9, including natural killer T cells and type 2 innate lymphoid cells [41]. Our tentative identification of the source of IL-9 in the OVA-sensitized AR model is in agreement with the suggestions of Kaplan and Chang $[42,43]$. However, the precise source of IL-9 should be confirmed in future work.

The downstream effects of IL-9 are primarily attributable to its receptor, IL-9R, which is expressed by effector but not naive T cells $[44,45]$. Of the various Th- 
cell subsets, Th2 and Th17 cells maximally express IL-9R [46]. In patients with asthma, IL-9R is expressed by both lung mast and polymorphonuclear cells [47, 48]. However, the precise cellular targets of IL-9 in the OVA-induced AR mouse model remain unclear.

We found that IL-9 neutralization was associated with broad anti-inflammatory effects, and major changes in the Th1, Th2, Th17, or Treg response clearly alleviated allergic symptoms in the AR model. These data indicate that Th-cell subsets do not operate independently; rather, they appear to work co-operatively and network. IL-9 is a key component of this process, so inhibiting this protein may be useful for the treatment of AR.

Our findings are limited to the AR model induced by OVA. It is unclear what effect anti-IL-9 Abs would have on AR mouse models sensitized by other antigens, such as house dust mites. In addition, Treg cells mainly secrete IL10 and TGF- $\beta$. It is worth noting that IL-4 can represent the Th2 subgroup, while IL-9 can represent the Th9 subgroup. However, IL-10 and TGF- $\beta$ did not represent the Treg subgroup.

It is noteworthy that because IL-4 was produced primarily by the Th2 subgroup, it can reflect the function of Th2. Similarly, IL-9 was produced primarily by the Th9 subgroup, enabling it can reflect the function of Th9. However, Treg cells mainly secrete IL-10 and TGF- $\beta$. IL10 and TGF- $\beta$ were not produced primarily by the Treg subgroup. The present study therefore does not involve cytokines from Treg cells.

In conclusion, we have shown for the first time that Th9 cells are involved in AR development, and that neutralization of IL-9 has broad anti-inflammatory effects. We expect that our results will improve the understanding of the pathogenesis of AR and facilitate the development of novel antibody-based therapies for the management of this disease.

\section{MATERIALS AND METHODS}

\section{Animals}

Eight-week-old female BALB/c mice, free of murine-specific pathogens, were obtained from the animal department at Shengjing Hospital, China Medical University (Shenyang, China). The mice were housed in a controlled environment with a 12/12-h light/dark cycle with free access to food and water. They were maintained on an ovalbumin (OVA)-free diet. The experimental procedures were approved by the ethical committee of Shengjing Hospital, China Medical University.

\section{Sensitization and antigen challenge}

$\mathrm{BALB} / \mathrm{c}$ mice were divided into four treatment groups of 10 mice each as follows: (1) control group mice, sensitized and challenged with saline (group A), (2) OVA group mice, sensitized and challenged with OVA (group $\mathrm{B}),(3)$ isotype group mice, treated with isotype Abs for anti-IL-9 (group C), and (4) anti-IL-9 group mice, treated with an anti-IL-9 Ab (group D).

The OVA group mice were sensitized on days 0,2 , $4,6,8,10,12$, and 14 by intraperitoneal (i.p.) injection with $1 \mathrm{mg} / \mathrm{mL}$ OVA (Sigma-Aldrich, St. Louis, MO, USA) and $20 \mathrm{mg} / \mathrm{mL}$ aluminum hydroxide (Sigma-Aldrich) in saline at a dose of $100 \mu \mathrm{L} /$ mouse.

After 2 weeks, the animals were challenged by daily nasal instillation of $100 \mu \mathrm{g}$ OVA in $20 \mu \mathrm{L}$ saline per mouse, by means of a micropipette, from day 15 to day 25 .

Mice from the isotype group and the anti-IL-9 group were given intranasal instillations of hamster IgG (isotype $\mathrm{Ab}$ for anti-IL-9, eBioscience, San Diego, CA, USA) and anti-IL-9 Abs (eBioscience), respectively, $30 \mathrm{~min}$ prior to the OVA challenge, at a dose of $10 \mu \mathrm{g}$ in $20 \mu \mathrm{L}$ saline per mouse. Control group mice were sensitized and challenged with saline instead of OVA at all stages.

\section{Evaluation of allergic symptoms induced after allergen challenge}

On day 25, during the 10-min period after the final intranasal OVA administration, the numbers of nasal rubbing motions and sneezes were recorded by four observers who were blinded to the experimental groups. The average values of the four observers' measurements were used for statistical analysis.

\section{Histopathology}

Two hours after the last challenge on day 25, the mice were sacrificed. The heads of five mice per group were removed and immersed in $4 \%$ buffered paraformaldehyde. After fixation, the heads were decalcified in 10\% ethylenediamine tetraacetic acid for 28 days. The specimens were embedded in paraffin wax and sectioned coronally at a thickness of $4 \mu \mathrm{m}$. The sections were stained with hematoxylin and eosin (H\&E) for eosinophils.

In four randomly selected fields from each section, the numbers of eosinophils in the nasal mucosa were counted under a microscope at $\times 200$ magnification, and the mean value for each field was calculated. The counts were made by two observers who were blinded to the treatments. 


\section{Collection of nasal mucosa}

The nasal mucosae of the remaining five mice in each group were obtained. The nasal mucosae were divided into two parts: one part was prepared into a singlecell suspension and centrifuged. After centrifugation, the supernatant was stored at $-80^{\circ} \mathrm{C}$ for cytokine measurement, while the pellet was used for Th1, Th2, Th9, Th17, and Treg cell percentage analysis. The second part was immediately snap-frozen in liquid nitrogen and stored at $-80^{\circ} \mathrm{C}$ for RNA extraction.

\section{RNA extraction/reverse transcription and real- time polymerase chain reaction (PCR)}

Total RNA was extracted with the TRIzol reagent (Invitrogen, Shanghai, China), and total RNA $(0.5 \mu \mathrm{g})$ was reverse-transcribed to complementary DNA with a PrimeScript RT kit (Takara, Dalian, China), according to the manufacturer's protocol. Real-time PCR was performed with SYBR Premix Ex Taq (Takara) on an ABI 7500 Real-time PCR System (Applied Biosystems, Foster City, CA, USA).

$\beta$-actin (a housekeeping gene) served as a control, while Ifn- $\gamma$, Il-4, Il-9, Il-17a, T-bet, Gata3, PU.1, interferon regulatory factor 4 (Irf4), Roryt, and Foxp 3 were the target genes. The following primer sequences were used (all $5^{\prime}$ to $3^{\prime}$ ): forward primer GCAGAAGGAGATTACTGCTCT, reverse primer GCTGATCCACATCTGCTGGAA for $\beta$-actin; forward primer CTGCTGATGGGAGGAGATGT, reverse primer TTTGTCATTCGGGTGTAGTCA for If $n-\gamma$; forward primer TGTACCAGGAGCCATATCCA, reverse primer TGTTCTTCGTTGCTGTGAGG for Il-4; forward primer GGGCATCAGAGACACCAAT, reverse primer GGACGGAGAGACACAAGCA for $\mathrm{Il}-9$; forward primer TCTCTGATGCTGTTGCTGCT, reverse primer CGTGGAACGGTTGAGGTAGT for $I l-17 a$; forward primer TACAACAGCCAGCCAAACAG, reverse primer CACCCTTCAAACCCTTCCTC for T-bet; forward primer TACCACCTATCCGCCCTATG, reverse primer GCCTCGACTTACATCCGAAC for Gata3; forward primer CTTCCAGTTCTCGTCCAAGC, reverse primer TTCTTCACCTCGCCTGTCTT for PU.1; forward primer ACTTGCCTTCACAACCGTCT, reverse primer CCCGAAAGAGTCAGGAATGA for Irf4; forward primer AGCCTTTCCCTTTCTGCACT, reverse primer CCATCACTTGCTGCTGTTGT for Roryt; and forward primer GCCAAGCAGAAAGATGACAG, reverse primer TTCCAGATGTTGTGGGTGAG for Foxp3.

mRNA levels were measured by the cycle threshold $\left(2^{-\Delta \Delta C T}\right)$ method and were normalized to $\beta$-actin levels. A no-template sample served as a negative control.

\section{Measurement of cytokine concentrations}

Levels of IFN- $\gamma$, IL-4, IL-9, and IL-17A in supernatants were measured with a Cytometric Bead Array (CBA) Flex Set (BD Biosciences, San Jose, CA, USA) according to the manufacturer's instructions. Briefly, four capture bead populations that had distinct fluorescence intensities and were coated with cytokine-specific capture Abs were mixed together in equal volumes; then, $50 \mu \mathrm{L}$ of each sample and $50 \mu \mathrm{L}$ of phycoerythrin (PE)-conjugated detection Abs were added to $50 \mu \mathrm{L}$ of the mixed-bead population. Each mixture was incubated for $3 \mathrm{~h}$ at room temperature in the dark so that sandwich complexes could form. Then, the beads were washed with wash buffer, and data were acquired with a BD FACSCanto II flow cytometer (BD Biosciences). FACSDiva and BD CBA software 4.2 (BD Biosciences) were used for the analyses.

The limits of detection were $0.5 \mathrm{pg} / \mathrm{mL}$ for IFN- $\gamma$, $0.3 \mathrm{pg} / \mathrm{mL}$ for IL-4, $10.7 \mathrm{pg} / \mathrm{mL}$ for IL-9, and $0.95 \mathrm{pg} / \mathrm{mL}$ for IL-17A. Zero values were assigned when levels were under these limits.

\section{Flow cytometric analysis of Th1, Th2, Th9, and Th17 cell percentages}

Cells were stimulated with $50 \mathrm{ng} / \mathrm{mL}$ phorbol myristate acetate (Sigma-Aldrich, St. Louis, MO, USA), $1 \mu \mathrm{g} / \mathrm{mL}$ ionomycin (Sigma-Aldrich), and $10 \mu \mathrm{g} / \mathrm{mL}$ GolgiStop (BD Biosciences) at $37^{\circ} \mathrm{C}$ under $5 \%(\mathrm{v} / \mathrm{v})$ $\mathrm{CO}_{2}$ for $6 \mathrm{~h}$, then stained with fluorescein isothiocyanatelabeled anti-CD4 Abs (BD Biosciences) and fixed and permeabilized with a fix/perm solution (eBioscience, San Diego, CA, USA) according to the manufacturer's instructions. The cells were then incubated with an allophycocyanin (APC)-labeled IFN- $\gamma$ Ab, APC-labeled IL-4 Ab, PE-labeled IL-9 Ab, and PE-labeled IL-17A Ab (BD Biosciences). Cells in the control group were stained with the isotype control. Samples were analyzed on a BD FACSCanto II flow cytometer (BD Biosciences), and data were evaluated with FlowJo software (ver. 7.6; TreeStar Inc., San Carlos, CA, USA).

\section{Flow cytometric analysis of Treg cell percentages}

Cells were stained with a fluorescein isothiocyanatelabeled CD4 Ab and a phycoerythrin-cyanin 7 (PE-Cy7)labeled CD25 Ab (BD Biosciences) and were fixed and permeabilized with a fix/perm solution (eBioscience) according to the manufacturer's instructions. The cells were then incubated with a PE-labeled FOXP3 Ab (BD Biosciences), and those in the control group were stained with a FOXP3 isotype control. Samples were analyzed on a BD FACSCanto II flow cytometer (BD Biosciences), and data were evaluated with FlowJo software (ver. 7.6; TreeStar Inc.). 


\section{Statistical analysis}

All results are expressed as the mean \pm SEM. Results from the different groups were compared through the non-parametric Kruskal-Wallis test, followed by the Mann-Whitney U-test. Statistical analyses were performed with SPSS software (ver. 13.0; SPSS Inc., Chicago, IL, USA). $P$ values $<0.05$ were considered to indicate statistical significance.

\section{ACKNOWLEDGMENTS}

We thank LiYing Hao (Department of Drug Toxicology, School of Pharmaceutical Sciences, China Medical University) for excellent technical assistance.

\section{CONFLICTS OF INTEREST}

No author has any possible conflict of interest.

\section{GRANT SUPPORT}

This research was supported by the National Natural Science Foundation of China (grant no. 81200730).

\section{REFERENCES}

1. Schoenwetter WF, Dupclay L Jr, Appajosyula S, Botteman MF, Pashos CL. Economic impact and qualityof-life burden of allergic rhinitis. Curr Med Res Opin. 2004;20:305-317.

2. Nathan RA.The burden of allergic rhinitis. Allergy Asthma Proc. 2007;28:3-9.

3. Lv X, Xi L, Han D, Zhang L. Evaluation of the psychological status in seasonal allergic rhinitis patients. ORL J Otorhinolaryngol Relat Spec. 2010;72:84-90.

4. Wang SB, Deng YQ, Ren J, Xiao BK, Liu Z, Tao ZZ. Exogenous interleukin-10 alleviates allergic inflammation but inhibits local interleukin-10 expression in a mouse allergic rhinitis model. BMC Immunol. 2014;15:9.

5. Wang SB, Deng YQ, Ren J, Xiao BK, Chen Z, Tao ZZ. Lactoferrin administration into the nostril alleviates murine allergic rhinitis and its mechanisms. Scand J Immunol. 2013;78:507- 515 .

6. Malmhäll C, Bossios A, Pullerits T, Lötvall J. Effects of pollen and nasal glucocorticoid on FOXP3+, GATA-3+ and T-bet + cells in allergic rhinitis. Allergy. 2007;62:10071013.

7. Reisinger J, Triendl A, Küchler E, Bohle B, Krauth MT, Rauter I, Valent P, Koenig F, Valenta R, Niederberger $\mathrm{V}$. IFN-gamma-enhanced allergen penetration across respiratory epithelium augments allergic inflammation. J Allergy Clin Immunol. 2005;115:973-981.

8. Cortelazzi C, Campanini N, Ricci R, De Panfilis G.
Inflammed skin harbours Th9 cells. Acta Derm Venereol. 2013;93:183-185.

9. Schlapbach C, Gehad A, Yang C, Watanabe R, Guenova E, Teague JE, Campbell L, Yawalkar N, Kupper TS, Clark RA. Human TH9 cells are skin-tropic and have autocrine and paracrine proinflammatory capacity. Sci Transl Med. 2014;6:219ra8.

10. Ma L, Xue HB, Guan XH, Shu CM, Zhang JH, Yu J. Possible pathogenic role of $\mathrm{T}$ helper type 9 cells and interleukin (IL)-9 in atopic dermatitis. Clin Exp Immunol. 2014;175:25-31.

11. McLane MP, Haczku A, van de Rijn M, Weiss C, Ferrante V, MacDonald D, Renauld JC, Nicolaides NC, Holroyd KJ, Levitt RC. Interleukin-9 promotes allergen-induced eosinophilic inflammation and airway hyperresponsiveness in transgenic mice. Am J Respir Cell Mol Biol. 1998;19:713-720.

12. Dugas B, Renauld JC, Pène J, Bonnefoy JY, Peti-Frère C, Braquet P, Bousquet J, Van Snick J, Mencia-Huerta JM. Interleukin-9 potentiates the interleukin-4-induced immunoglobulin (IgG, IgM and IgE) production by normal human B lymphocytes. Eur J Immunol. 1993;23:1687-1692.

13. Louahed J, Toda M, Jen J, Hamid Q, Renauld JC, Levitt RC, Nicolaides NC. Interleukin-9 upregulates mucus expression in the airways. Am J Respir Cell Mol Biol. 2000;22:649-656.

14. Soussi-Gounni A, Kontolemos M, Hamid Q. Role of IL-9 in the pathophysiology of allergic diseases. J Allergy Clin Immunol. 2001;107:575-582.

15. Kaplan MH.Th9 cells: differentiation and disease. Immunol Rev. 2013;252:104-115.

16. Richard M, Grencis RK, Humphreys NE, Renauld JC, Van Snick J. Anti-IL-9 vaccination prevents worm expulsion and blood eosinophilia in Trichuris muris-infected mice. Proc Natl Acad Sci USA. 2000;97:767-772.

17. Li H, Nourbakhsh B, Ciric B, Zhang GX, Rostami A. Neutralization of IL-9 ameliorates experimental autoimmune encephalomyelitis by decreasing the effector T cell population. J Immunol. 2010;185:4095-4100.

18. Cheng G, Arima M, Honda K, Hirata H, Eda F, Yoshida N, Fukushima F, Ishii Y, Fukuda T. Anti-interleukin-9 antibody treatment inhibits airway inflammation and hyperreactivity in mouse asthma model. Am J Respir Crit Care Med. 2002;166:409-416.

19. Staudt V, Bothur E, Klein M, Lingnau K, Reuter S, Grebe N, Gerlitzki B, Hoffmann M, Ulges A, Taube C, Dehzad N, Becker M, Stassen M, et al. Interferon-regulatory factor 4 is essential for the developmental program of $\mathrm{T}$ helper 9 cells. Immunity. 2010;33: 192-202.

20. Li H, Rostami A. IL-9: basic biology, signaling pathways in CD4+ T cells and implications for autoimmunity. $\mathrm{J}$ Neuroimmune Pharmacol. 2010;5:198-209.

21. Elyaman W, Bradshaw EM, Uyttenhove C, Dardalhon V, Awasthi A, Imitola J, Bettelli E, Oukka M, van Snick 
J, Renauld JC, Kuchroo VK, Khoury SJ. IL-9 induces differentiation of TH17 cells and enhances function of FoxP3+ natural regulatory T cells. Proc Natl Acad Sci USA. 2009; 106:12885-12890.

22. Wu B, Huang C, Kato-Maeda M, Hopewell PC, Daley CL, Krensky AM, Clayberger C. IL-9 is associated with an impaired Th1 immune response in patients with tuberculosis. Clin Immunol. 2008;126:202-210.

23. Finiasz MR, Franco MC, de la Barrera S, Rutitzky L, Pizzariello G, del Carmen Sasiain M, Renauld JC, Van Snick J, Fink S. IL-9 promotes anti-Mycobacterium leprae cytotoxicity: involvement of IFNgamma. Clin Exp Immunol. 2007;147:139-147.

24. Veldhoen M, Uyttenhove C, van Snick J, Helmby H, Westendorf A, Buer J, Martin B, Wilhelm C, Stockinger B. Transforming growth factor-beta 'reprograms' the differentiation of $\mathrm{T}$ helper 2 cells and promotes an interleukin 9-producing subset. Nat Immunol. 2008;9:13411346.

25. Kim MS, Cho KA, Cho YJ, Woo SY. Effects of interleukin-9 blockade on chronic airway inflammation in murine asthma models. Allergy Asthma Immunol Res. 2013;5:197-206.

26. Singh TP, Schön MP, Wallbrecht K, Gruber-Wackernagel A, Wang XJ, Wolf P. Involvement of IL-9 in Th17associated inflammation and angiogenesis of psoriasis. PLoS One. 2013;8:e51752.

27. Temann UA, Ray P, Flavell RA. Pulmonary overexpression of IL-9 induces Th2 cytokine expression, leading to immune pathology. J Clin Invest. 2002;109:29-39.

28. Infante-Duarte $\mathrm{C}$, Horton HF, Byrne MC, Kamradt T. Microbial lipopeptides induce the production of IL-17 in Th cells. J Immunol. 2000;165:6107-6115.

29. Ivanov II, McKenzie BS, Zhou L, Tadokoro CE, Lepelley A, Lafaille JJ, Cua DJ, Littman DR. The orphan nuclear receptor RORgammat directs the differentiation program of proinflammatory IL-17+ T helper cells. Cell. 2006;126:1121-1133.

30. Quan SH, Zhang YL, Han DH, Iwakura Y, Rhee CS. Contribution of interleukin 17A to the development and regulation of allergic inflammation in a murine allergic rhinitis model. Ann Allergy Asthma Immunol. 2012;108:342-350.

31. Wakashin H, Hirose K, Maezawa Y, Kagami S, Suto A, Watanabe N, Saito Y, Hatano M, Tokuhisa T, Iwakura Y, Puccetti P, Iwamoto I, Nakajima H. IL-23 and Th17 cells enhance Th2-cell-mediated eosinophilic airway inflammation in mice. Am J Respir Crit Care Med. 2008;178:1023-1032.

32. Zhao J, Lloyd CM, Noble A. Th17 responses in chronic allergic airway inflammation abrogate regulatory $\mathrm{T}$-cellmediated tolerance and contribute to airway remodeling. Mucosal Immunol. 2013;6:335-346.

33. Cao PP, Li HB, Wang BF, Wang SB, You XJ, Cui YH,
Wang DY, Desrosiers M, Liu Z. Distinct immunopathologic characteristics of various types of chronic rhinosinusitis in adult Chinese. J Allergy Clin Immunol. 2009;124:478-484.

34. Mo JH, Chung YJ, Kim JH. T cell transcriptional factors in allergic rhinitis and its association with clinical features. Asia Pac Allergy. 2013;3:186-193.

35. Xu G, Mou Z, Jiang H, Cheng L, Shi J, Xu R, Oh Y, Li H. A possible role of CD4+CD25+ T cells as well as transcription factor Foxp3 in the dysregulation of allergic rhinitis. Laryngoscope. 2007;117:876-880.

36. Lee SM, Gao B, Dahl M, Calhoun K, Fang D. Decreased FoxP3 gene expression in the nasal secretions from patients with allergic rhinitis. Otolaryngol Head Neck Surg. 2009; 140:197-201.

37. Yao X, Kong Q, Xie X, Wang J, Li N, Liu Y, Sun B, Li Y, Wang G, Li W, Qu S, Zhao H, Wang D, et al. Neutralization of interleukin-9 ameliorates symptoms of experimental autoimmune myasthenia gravis in rats by decreasing effector $\mathrm{T}$ cells and altering humoral responses. Immunology. 2014;143:396-405.

38. Yao Z, Kanno Y, Kerenyi M, Stephens G, Durant L, Watford WT, Laurence A, Robinson GW, Shevach EM, Moriggl R, Hennighausen L, Wu C, O'Shea JJ. Nonredundant roles for $S t a t 5 \mathrm{a} / \mathrm{b}$ in directly regulating Foxp3. Blood. 2007;109:4368-4375.

39. Lan F, Zhang N, Zhang J, Krysko O, Zhang Q, Xian J, Derycke L, Qi Y, Li K, Liu S, Lin P, Bachert C. Forkhead box protein 3 in human nasal polyp regulatory T cells is regulated by the protein suppressor of cytokine signaling 3 . J Allergy Clin Immunol. 2013;132:1314-1321.

40. Hausding M, Tepe M, Ubel C, Lehr HA, Röhrig B, Höhn Y, Pautz A, Eigenbrod T, Anke T, Kleinert H, Erkel G, Finotto $\mathrm{S}$. Induction of tolerogenic lung CD4+ T cells by local treatment with a pSTAT-3 and pSTAT-5 inhibitor ameliorated experimental allergic asthma. Int Immunol. 2011;23:1-15.

41. Gu ZW, Wang YX, Cao ZW. T-Helper Type 9 Cells Play a Central Role in the Pathogenesis of Respiratory Epithelial Adenomatoid Hamartoma. Medicine (Baltimore). 2015;94:e1050.

42. Kaplan MH, Hufford MM, Olson MR. The development and in vivo function of T helper 9 cells. Nat Rev Immunol. 2015; 15:295-307.

43. Chang HC, Sehra S, Goswami R, Yao W, Yu Q, Stritesky GL, Jabeen R, McKinley C, Ahyi AN, Han L, Nguyen ET, Robertson MJ, Perumal NB, et al. The transcription factor PU.1 is required for the development of IL-9-producing T cells and allergic inflammation. Nat Immunol. 2010;11:527534.

44. Cosmi L, Liotta F, Angeli R, Mazzinghi B, Santarlasci V, Manetti R, Lasagni L, Vanini V, Romagnani P, Maggi E, Annunziato F, Romagnani S. Th2 cells are less susceptible than Th1 cells to the suppressive activity of CD25+ regulatory thymocytes because of their responsiveness to 
different cytokines. Blood. 2004;103:3117-3121.

45. Druez C, Coulie P, Uyttenhove C, Van Snick J. Functional and biochemical characterization of mouse P40/IL-9 receptors. J Immunol. 1990;145:2494-2499.

46. Nowak EC, Weaver CT, Turner H, Begum-Haque S, Becher B, Schreiner B, Coyle AJ, Kasper LH, Noelle RJ. IL-9 as a mediator of Th17-driven inflammatory disease. J Exp Med. 2009;206:1653-1660.

47. Abdelilah S, Latifa K, Esra N, Cameron L, Bouchaib L, Nicolaides N, Levitt R, Hamid Q. Functional expression of IL-9 receptor by human neutrophils from asthmatic donors: role in IL-8 release. J Immunol. 2001;166:2768-2774.
48. Kearley J, Erjefalt JS, Andersson C, Benjamin E, Jones CP, Robichaud A, Pegorier S, Brewah Y, Burwell TJ, Bjermer L, Kiener PA, Kolbeck R, Lloyd CM, et al. IL-9 governs allergen-induced mast cell numbers in the lung and chronic remodeling of the airways. Am J Respir Crit Care Med. 2011;183:865-875. 